\title{
Два сюжета из истории русского отщепенства: позиции и технологии литературного противостояния
}

\begin{abstract}
Lutsevich Ludmila, Dva sjužeta iz istorii russkogo otščepenstva: pozicii i tehnologii literaturnogo protivostojanija (Two Motives of Russian Dissident Movement: Background and Literature Antagonism Technologies). „Poznańskie Studia Slawistyczne” 6. Poznań 2014. Publishing House Science and Innovate, pp. 169-184. ISBN 978-83-63795-51-1. ISSN 2084-3011.

In the Russian social thinking, the notion ,dissident movement” has appeared twice. For the first time, as a historical and theoretical term in the essay The Dissident (1866) by Nikolay Sokolov, and then, a century later in the autobiographical The Confession of a Dissident (1990) by Alexander Zinoviev. Zinoviev considered ,the dissident movement” to be social practices, which allow for social generalization. The first part of the article represents the thinking on the initial stage of dissident movement understanding. The Russian essay writers of the $60 \mathrm{~s}$ of $19^{\text {th }}$ century analyzed this phenomenon based on the European experience, and connected it with the revolutionary struggle against the government and society to build socialist future for the mankind. In the second part of the article, the ,dissident movement” is seen as a trial of a philosopher and sociologist who lived in socialism and communist period, in order to describe the merciless technologies to eliminate an individual from the Soviet intelligent society, in the $60 \mathrm{~s}$ and $70 \mathrm{~s}$ of $20^{\text {th }}$ century.
\end{abstract}

Keywords: dissident; antagonism; social publicism; autobiographic confession; revolutionary fight; sociological technology

В русской общественной мысли и литературе дважды была зафиксирована актуализация отщепенства: первый раз в 1866 г. преимущественно как историко-теоретического понятия, описанного в публицистическом сочинении Отщепенць, второй раз - в 1990 г. как социальная практика и социологическое обобщение, получившие выражение в автобиографической книге Исповедь отщееленца.

В данной статье внимание сосредоточено не столько на противостоянии как таковом (эта тема, само собой разумеется, определяется цитируемыми источниками), сколько на его литературных формах. 
В первой части статьи отщепенство рассматривается как попытка теоретического освоения русскими публицистами $60-\mathrm{X}$ гг. XIX в. этого явления на европейском материале; во второй - как опыт осмысления писателем, философом-социологом технологии отторжения личности в среде российской научной интеллигенции в 60-70-е гг. XX в.

\section{1.}

В 1866 г. в Санкт-Петербурге увидела свет историко-публицистическая книга под названием Отщеепенцы, автором которой был, как указано на обложке, Николай Васильевич Соколов (1832-1889). Сейчас это фактически забытая фигура (Кузнецов 1981: 244-322), а в свое время достаточно популярная, особенно в среде революционно-демократической интеллигенции. Николай Соколов - дворянин, блистательный офицер Генерального штаба, благодаря своим незаурядным способностям, смелости, решительности, активно продвигался по служебной лестнице. В 1860 г., находясь в отпуске в Париже, познакомился с Пьером Прудоном, увлекся экономическими идеями французского социалиста-анархиста. А через два года ушел в отставку в чине подполковника (ему было всего 30 лет) и полностью изменил образ жизни и характер своей деятельности, став сотрудником радикального журнала „Русское слово”, на страницах которого освещал финансово-экономические вопросы.

Как убедительно доказал проф. Борис П. Козьмин, в написании книги Отщеленцы, помимо Соколова, принимал самое непосредственное участие его близкий друг, соратник по журналу, популярный литературный критик и публицист Варфоломей Александрович Зайцев (1842-1882). Ученый при этом опирался на письменное свидетельство известного революционера-народника, близкого товарища Соколова и Зайцева - Михаила Сажина, который на запрос Козьмина относительно авторов книги писал так:

Отвечаю на ваш вопрос об авторстве книги Отщепенцы. 1) В разное время (в 70-х годах) лично слышал от Н.В. Соколова и В. Ал. Зайцева, что они оба писали (выделено Сажиным) книгу Отщепенцы, причем первую половину (приблизительно) писал Зайцев, а вторую Соколов. 2) Инициатором написания книги был Соколов. 
Книга была отпечатала при новом законе о цензуре (уничтожена предварительная цензура). Оба автора допускали случай задержания книжки цензурою и даже ее судебного преследования по ее выходе, поэтому было условлено, что Соколов берет на себя всю ответственность, поэтому он, Соколов, заявил себя автором Отщеленцев официально перед цензурою (Козьмин 1982: 377-378).

Социально-политические взгляды Николая Соколова и Варфоломея Зайцева, хоть и отличались в некоторых деталях, но в целом определялись идеологией нигилизма, разделяемой публицистами „Русского слова” (помимо Зайцева и Соколова, это Дмитрий Писарев, Григорий Благосветлов, Николай Шелгунов). Русский нигилизм как „обозначение демократически настроенной разночинной интеллигенции 60-х годов" (Козьмин 1982: 227), „как материалистически-естественнонаучное мировоззрение”, „самополагание” и „поведение” (Михайлов 2000: 609) был направлен на критическое переосмысление и отрицание культурных, социальных, нравственных и эстетических ценностей, препятствующих, как считали его приверженцы, развитию современного общества. Нигилисты - „новые люди”, отличались от окружающих „особой системой ценнностей, которая превращала их в «отщепенцев»” (Щербакова 2008: 88). Нигилизм напрямую соотносился с более широко трактуемой идеей отщепенства, воспринятой как универсальная и всеобъемлющая идея протеста. Публицисты „Русского слова” использовали различные средства для пропаганды революционности и социального экстремизма, опираясь при этом преимущественно на европейский исторический опыт. В процессе создания „истории революционных движений Запада”, они пытались соединить современные им теории социальной революции с идеями утопического социализма (Кузнецов 1984: 26). Особенно пристальным было наблюдение за развитием французской социально-общественной мысли.

Не случайно непосредственным толчком для создания книги русскими авторами послужили вышедшие во Франции в 1865 г. очерки молодого революционно настроенного писателя Жюля Валлеса (Jules Vallès) Oтщеепенцы (Les réfractaires). О замысле и истории создания русской книги имеется только краткая информация в Автобиографии самого Соколова, который писал о себе в 3 лице таким образом:

Случайно сидя у Доминика (...) прочел он газету „La Presse” Эмиля-де-Жирардена о Жюле Валлесе и его книге Les refractaires. Вышел из Cafe, купил эту книгу 
и помчался к Зайцеву. Тотчас же отправил Ножина в „Петербургские ведомости” для напечатания объявления: „Печатаются и выйдут на днях Отщепенцы - под редакцией Н. Соколова” (Кузнецов 1981: 301).

Дав объявление об издании Les refractaires, Соколов не знал еще, что книга Жюля Валлеса составлена из газетных и журнальных корреспонденций, объединенных общей темой отверженных интеллигентов: непризнанных молодых поэтов, художников, ученых, изобретателей, живущих в нужде и ненавидящих окружающее их общество. Как христианские отшельники некогда удалялись в пустынь от разрушительных мирских соблазнов, так отщепенцы Валлеса замыкаются в своем индивидуальном неприятии современной им цивилизации. Для русских радикалов такого отщепенства, очевидно, было недостаточно, поэтому перевод книги Валлеса не состоялся, но появился иной замысел, в реализации которого был использован, как и у Валлеса, принцип монтажа текстов. Соколов в Автобиографии отметил, что из Валлеса он перевел только начало: „Валлес оказался плох, из него годились только четыре первые страницы, а остальные сам придумал" (Кузнецов 1981: 301). Новый замысел Соколова определялся желанием дать русским читателям некую квинтэссенцию европейской социал-христианской мысли, представить на русском языке историю развития отщепенства как историю протеста против „развратного общества практических людей” (Соколов 1984: 303). Поскольку договор с издателем был заключен, а времени для оригинальной работы было крайне мало, то составители, отказавшись от перевода французской книги, избрали путь компилляции фрагментов из произведений европейских писателей, освещавших разные формы протеста против общества. Русские авторы перечитали десятки книг, выбрали и перевели соответствующий их целям материал, ввели небольшие комментарии и связки между частями. В течение пяти недель книга была не только составлена, но и издана тиражем в две тысячи экземпляров. 4 апреля 1866 г., как сообщил Соколов, он сдал книгу в цензурный комитет в 9 часов утра. Через два часа Дмитрий Каракозов выстрелил в Александра II, положив начало „охоты на царя”. Последовали репрессивные меры, коснувшиеся и печати: почти весь тираж Отщепенцев оказался арестованным. Думается, что и вне этого драматического стечения 
обстоятельств книга не получила бы одобрения цензора. Но в условиях, когда было осуществлено покушение на жизнь первого лица империи, чиновник Цензурного комитета был особенно бдителен. В своем отчете он подчеркнул, что книга представляет прямую угрозу для „цивилизованного общества”, поскольку основные ценности - „вера, политика, власть, гражданское и судебное устройство, правила нравственности подвергаются в ней самым необузданным нападениям" (Козьмин 1982: 379). Книга, как считал цензор, была опасна еще и потому, что в ней „коммунистические и революционные доктрины представляются в непосредственной связи с первобытным христианством, как логическое и естественное развитие истинного учения спасителя и апостолов" (Козьмин 1982: 379). Цензурный комитет немедленно возбудил преследование Николая Соколова. Дело рассматривалось в Петербургской судебной палате, которая постановила книгу уничтожить, a ее автора заключить в Петербургский тюремный замок (затем его перевели в Петропавловскую крепость) на год и четыре месяца. После истечения срока в 1868 г. Соколов был выслан в Архангельскую губернию. В 1870 в связи с ухудшением состояния здоровья, подорванного в крепости, перевезен, по его просьбе, в более теплую климатическую зону - в Астраханскую губернию, в захолустное местечко Красный Яр, откуда через два года с помощью чайковцев - членов петербургской подпольной народнической организации, бежал. В конце 1872 года он оказался в Цюрихе, где еще до его приезда эмигранты переиздали $\mathrm{Om}$ шепенщев и сумели большую часть тиража переправить в Россию.

Структурно книга, составленная Соколовым и Зайцевым, состояла из предисловия, заключения и двух основных частей.

Понятие отщепенство истолковано в книге неоднозначно. В качестве предисловия в книгу включено вступление, переведенное из книги Жюля Валлеса Отщеепенщы, где намечена некая типологическая парадигма отщепенца, при этом для автора не столь существенно, кем являются отщепенцы („спокойные безумцы”, „восторженные труженники”, „мужественные ученые”, „беспокойные люди”), важны позиции и идеи, руководствуясь которыми, они „проживают свою жизнь”: „отыскивают причины общественных зол и бедствий, проповедуют вечную республику, блаженное социальное устройство, личную свободу, гражданскую солидарность, экономическую правду” (Соколов 
1984: 167). Отщепенцы здесь - носители социалистических жизненных принципов. Но отщепенство далеко не всегда соотносится с какой-либо четко выраженной идеологией. Отщепенцами могут быть наиболее проницательные из современников, они предчувствуют гибель устоявшегося, старого, мира и потому дистанцируются, откалываются от него. Отщепенцы зачастую идеалисты-мечтатели, „воображающие, что им непременно нужно выполнить какое-то призвание, совершить какое-то священнодействие, защитить какое-нибудь знамя”, для них невыносима пошлость рутинной практической жизни, они не желают подчиниться общей доле, поэтому оказываются „в страшном одиночестве” (Соколов 1984: 167). Отщепенцы - великодушные храбрецы и благородные герои, которые способны бесстрашно „смеяться в глаза практической жизни”, и за это она мстит им, губя „их смертью медленною, в продолжительной агонии, полной жестоких огорчений, тяжких страданий, бесчеловечных мучений” (Соколов 1984: 168). Итак, во вступлении, как видно, доминирует образ отщепенца-отшельника, не принимающего общественного устройства и по-своему выражающего индивидуальный бунт, но ценящего превыше всего свою личную свободу и независимость (разновидность типа „лишнего человека” в русской литературе). Иной характер имеет основная часть книги, где на первый план выдвигается отщепенец-борец, направляющий свои усилия на изменение социальных основ и устоев (аналог „нового человека"). На разных этапах исторического развития общества отщепенцами были, в представлениях русских авторов, стоики и христиане, сектанты и утописты, социалисты и нигилисты.

Основная часть книги состоит из двух частей, первая из которых Историческое отщепенство включала четыре обзорных очерка: I. Стоики (+литературный портрет Тит Лабиен); II. Христиане; III. Секты (+эссе Как пропадают верования); IV. Утописты (+очерк Развалины). Вторая часть - Современное отщепенство, содержала обзорный очерк I. Сочиалисты и два монографических очерка II. Фурье, III. Прудон. Авторы скомпоновали книгу в основном из фрагментов малодоступных в то время сочинений западноевропейских мыслителей, размышлявших о формах и методах личного и общественного противостояния существовавшим режимам (от античности до 60-х гг. XIX в.). Стоит отметить, что, желая вызвать симпатии 
современников к идее революции, радикалы не чуждались обращения к библейским сюжетам и образам, к религиозной истории и патристике. По этому пути пошел и Соколов, доказывая, что социалистические идеи не противоречат христианским. Публицист обрушил свой гнев на главный, как он считал, порок цивилизации - несправедливо присвоенную собственность: „Кто защищает собственность, основанную на тунеядстве и лихоимстве, тот, значит, отрицает здравый смысл и правду, тот плюет на Евангелие и распинает Христа” (Соколов 1984: 293); „Все отщепенцы, начиная с апостолов и отцов церкви и кончая Прудоном, отрицали собственность" (Соколов 1984: 296). Христа и его учеников он назвал „отщепенцами фарисейского общества” (Соколов 1984: 303), а своих современников-социалистов - „отщепенцами буржуазного порядка” (Соколов 1984: 264). „Как христиане были отщепенцами римского мира, так точно являются и социалисты отщепенцами старой европейской цивилизации. Как те, так и другие - люди верующие, ведущие борьбу с лицемерием и подлостью” (Соколов 1984: 278). Себя автор именовал „евангельским нигилистом”, „отщепенцем-нигилистом". Отщепенцев прошлого и настоящего Соколов объединил в едином протесте против социальной несправедливости, в борьбе за свободу, равенство и братство. Любопытно, что среди отщеепенцев оказались многочисленные еретики Средневековья, Томас Мюнцер (Thomas Müntzer), Томас Мор (Thomas More), Томмазо Кампанелла (Tommaso Campanella), Константин Франсуа Вольней (Constantin Francois Volney), Луи Антуан Сен-Жюст (Louis Antoine de Saint-Just), Гракх Бабёф (Gracchus Babeuf), а также „апостолы XIX века": Шарль Фурье (Charles Fourier) и Пьер-Жозеф Прудон (PierreJoseph Proudhon). В Заключении автор цитировал Нагорную проповедь: „Блаженны алчущие и жаждущие правды!” и Творения Иоанна Златоуста, перетолковывая идеи и образы христианства в духе социализма - живого Отщеепенства (Соколов 1984: 303-304).

В целом, конечно, следует сказать, что Отщцепенцы русских авторов - сочинение не только эклектическое, но и противоречивое. Однако это не помешало ему стать одним из самых популярных среди радикальной молодежи 60-80-х гг. Петр Кропоткин отмечал, что книга и статьи Соколова „обратили многих в России в социализм” (Кропоткин 1966: 362), а Николай Морозов видел в книге, кроме пропаганды социализма, 
„поэзию и восторженный романтизм, возвеличивание самоотвержения и самопожертвования во имя идеала" (Морозов 1933: 119).

Привлекает внимание еще один любопытный момент. В определении характера отщепенца появляется, вольно или невольно, некий биографический компонент, характерный как для французского, так и для русских авторов: „отщепенцы те, которые делали все и ничем не сделались; которые учились всему: правам, медицине, естествознанию, военным наукам, математике - и не приобрели ни чина, ни диплома, ни превилегии, ни ученой степени" (Соколов 1984: 167). Отмечается также способность отщепенцов не привязываться к тому стабильному положению, которое давало общество, акцентируется независимость и смелость в изменении образа жизни, в соответствии с определенными убеждениями: „отщепенец - профессор, сбросивший свою мантию, - офицер, променявший мундир на цветную рубашку волонтера, - адвокат, пошедший в актеры, священник, сделавшийся журналистом” (Соколов 1984: 167). Напомню, что Варфоломей Зайцев, отличавшийся большими способностями, учился на юридическом факультете Петербургского университета, медицинском факультете Московского университета, в Петербургской медикохирургической академии, но курса нигде не закончил. Не имея средств к существованию, он вынужден был заняться журналистикой и вскоре стал деятельным сотрудником „Русского Слова”. Николай Соколов, как уже отмечалось, также в корне изменил характер своей деятельности.

В реальной жизни Соколов и Зайцев разделили судьбы своих героев: они оказались в ряду отщепенцев - революционеров-социалистов, бакунцев-анархистов, государственных преступников, лишившихся родины, закончивших свою жизнь в нищите, но до конца сохранивших верность Отщеленству в „отрицании существующего порядка грабежа и насилия” (Соколов 1984: 301). Для русских публицистов XIX в. отщеленство преимущественно связано с революционной борьбой против власти и общества за социалистическое будущее человечества.

Второй сюжет литературного противостояния иного рода, и связан он с именем известного русского ученого и писателя Александра 
Александровича Зиновьева (1922-2006). Зиновьев жил при реальном социализме/коммунизме, считал себя его „негативным продуктом”, резко критиковал воплощение этой общественной формации в СССР и в то же время утверждал, что в идеале не существует такого социального устройства, которое было бы лучше, чем коммунизм (Зиновьев 2008: 502). О том, как он стал на путь „социального индивидуализма” и остался верен ему до конца Зиновьев рассказал в своей Исповеди отщепенца (1990). Эта книга объединила в себе множество различных линий и сюжетов, но сквозными стали три: 1) автобиографическое повествование о жизни и судьбе русского человека - мальчика, юноши, воина, студента, ученого, писателя, социолога-философа Александра Зиновьева, 2) документальное свидетельство об исторических испытаниях, которые выпали на долю его поколения и народа в целом, а также 3) результаты многолетних философско-социологических наблюдений, размышлений и выводов относительно наиболее характерных и значимых явлениях советской и постсоветской эпох. Каждая из линий имеет свои многочисленные и разнообразные ответвления, но их общая совокупность дала возможность автору представить картину „русского коммунизма”.

Александр Зиновьев родился в 1922 г. в Костромской области в большой крестьянской семье. С детства отличался блестящими способностями и как лучший ученик был направлен в московскую школу, которую закончил с отличием. В 1939 г. поступил в Московский институт философии, литературы и истории, здесь вошел в антисталинский кружок, был исключен из института, подвергся аресту, бежал, скитался по стране, скрываясь от преследований, а затем добровольцем пошел в армию. Уже в юности обозначилась позиция противостояния власти. В Великую Отечественную войну Зиновьев воевал в кавалерии, в танковых и в летных частях, имел ранение, награды и отличия. В 1946 г. поступил на философский факультет МГУ, закончил его с отличием, учился в аспирантуре, защитил кандидатскую и докторскую диссертации, стал профессором, заведовал кафедрой логики, двадцать четыре года проработал в Институте философии Академии наук СССР. Диссидентом никогда себя не считал, но разгром Пражской весны в августе 1968 г. воспринял как личное оскорбление: „Я тогда сказал (...), что такое терпеть нельзя, что за это надо мстить «Им», что «Им» надо дать 
в морду. С тех пор мысль «дать Им в морду» уже не оставляла меня»" (Зиновьев 2008: 412). И нашел способ - обратился к литературе. Зрелый человек, крупный ученый, имевший международную известность, принципиально изменил сферу деятельности, уйдя от чистой науки в публицистику, сатирическую литературу, таким образом выражая свой бунтарский протест против „советизма”. Отторгнутый своей страной, выдворенный за границу, он и там продолжил литературную деятельность, став одним из „самых значительных современных русских писателей” (Зиновьев 2008: 478). Но и на Западе, по его признанию, „остался одиночкой” (Зиновьев 2008: 472). Сохранив личную независимость, в очередной раз оказался „в резком конфликте с общепринятым" (Зиновьев 2008: 478).

Как отмечал автор, после выезда за границу его именовали диссидентом, антисоветчиком, антикоммунистом (Зиновьев 2008: 8). Он же себя называл отщепенцем, не вписывающимся ни в какую социальную систему - ни в советскую ни в западную (Зиновьев 2008: 8). Отщеепенец Зиновьева - это сложно организованная личность: интеллектуал, принципиально отказавшийся от борьбы за социальный успех и совершенно сознательно избравший конфликт с обществом; трезвый наблюдатель происходящего, способный делать точные выводы и принимать самостоятельные решения; а также традиционно бунтарь, мятежник, индивидуалист, одиночка.

В исповеди писатель органично совместил две позиции: 1) биографического повествователя, рассказывающего о процессе внутреннего становления личности отщепенца: „Я рос и созревал духовно вместе с превращением коммунистического социального строя в моей стране в зрелый социальный организм. В этом процессе возник, рос и взрослел мой конфликт с моим обществом, мой личный бунт в нем и против него" (Зиновьев 2008: 22); 2) ученого - наблюдателя общественных нравов, фиксировавшего реакцию общества на явление отщепенства: „общество само провоцирует отщепенца на явный личный бунт и обрушивает на него всю мощь своей власти и ненависти” (Зиновьев 2008: 22). Автор описал как причины, обусловливающие противостояние индивида и общества, что в принципе актуализирует/формирует идеологию отщепенства, так и сам процесс отторжения личности коллективом, „выталкивание” ее в отщепенцы. 


\section{В главе Сочиальный отщеепенец Зиновьев пояснял:}

Отщепенцами в Советском Союзе называют лиц, которые по тем или иным причинам вступают в конфликт со своим коллективом и даже с обществом в целом, противопоставляют себя им и оказываются исключенными из них. (...) Социальный отщепенец является одиночкой, бунтующим против своего социального окружения. За это он наказывается либо уничтожением в качестве гражданской личности, либо подвергается остракизму (Зиновьев 2008: 21).

Не останавливаясь на конкретных конфликтах, которые возникали между Зиновьевым и его „окружением”, отмечу, что со временем писатель выработал определенную систему поведенческих правил - „зиновьйога", которой старался следовать сам и пропагандировал ее среди своих друзей. Система включала этические принципы, известные в христианстве и буддизме, например:

Я отвергаю стремление к материальному благополучию (...) истинное наслаждение жизнью - в самом факте жизни. А для этого нужны простота, ясность, умеренность, душевное здоровье (...) исключить борьбу за жизненные блага как цель жизни, - развить духовный мир и культуру духовного общения (Зиновьев 2008: 352).

При этом Зиновьев неоднократно подчеркивал, что он, создавая свой „кодекс”, учитывал социально-исторические факторы и ориентировался прежде всего на самого себя - человека XX века, выросшего в атеистическом государстве, интеллектуала, знакомого с высшими достижениями науки и культуры, зоркого наблюдателя обыденной жизни советских людей. Анализ конкретных фактов из личной жизни приводил к формулировке правил общечеловеческого содержания, типа:

нельзя доверяться людям полностью. Надо всегда принимать во внимание то, что они могут тебя подвести, обмануть, сделать тебе пакость. Это в особенно сильной мере касается близких тебе людей. (...) они, зная тебя и рассчитывая на близость, меньше опасаются расплаты за свои подлости. Враги человека, говорил Христос, суть ближние его (Зиновьев 2008: 355).

Отщепенец Зиновьева обладал универсальной системой принципов и понятий, однако общество, в представлении писателя, еще не созрело для ее последовательной реализации. Именно этим он объяснял стремление „окружения” отторгнуть своих наиболее „продвинутых” представителей. 
Технология отторжения, как показал Зиновьев, включает последовательно осуществляемые методы и приемы. В целом для „получения” такого „продукта”, как отщепенец, общество и власти используют комплекс различных мероприятий. Автор описал „выталкивание индивида в отщепенцы” практически (на уровне событий, произошедших в его жизни) и теоретически (на уровне наблюдения и выявления социальной технологии, используемой властью и обществом).

Процесс отторжения проходил несколько стадий, каждая из которых имела свою специфику.

1) „Сначала окружение будущего отщепенца проявляет в отношении его настороженность" (Зиновьев 2008: 403). Опираясь на множество разнообразных фактов, автор показал, как вокруг него - „кандидата в отщепенцы” - создавалась атмосфера подозрительности, напряжения, опасливости, особой бдительности со стороны его профессионального ,окружения”:

Я еще не встал на путь открытого бунта (...) а в моем окружении уже почувствовали мое отторжение (...) и вносили в это отторжение свою лепту. Вносили по мелочам, но этих мелочей было много. Они углубляли и расширяли психологическую и идейную пропасть между мною и окружающими людьми (Зиновьев 2008: 403).

2) „Затем принимаются предупредительные меры” (Зиновьев 2008: 403). В мирные семидесятые годы, когда диссидентство в СССР превратилось в достаточно широкое движение противостояния, власти, пытаясь предотвратить новые попытки бунта, стали использовать различные ограничения и запреты с целью предотвратить „падение” и вернуть на путь истинный „заблудшего” гражданина. Предупредительные меры относительно Зиновьева после публикации его книг на Западе выражались в том, что его кандидатура отклонялась без объяснения причин при выборах в Академию наук и при выдвижении на государственные премии, его труды перестали издавать, резко уменьшилась его нагрузка в университете, сократилось число студентов и аспирантов, писавших под его руководством научные работы; его ученики подвергались дискриминации, что привело в конечном итоге не только к отмеживанию учеников от учителя, но и к предательству (Зиновьев 2008: 403-404). Знаки внимания со стороны зарубежных 
научных сообществ к исследованиям Зиновьева (публикации за рубежом, приглашения на конференции, избрание почетным членом Финляндской Академии наук, приезд в связи с этим самого президента Академии фон Вригта, многочисленных иностранных журналистов и т.п.) вызвали дополнительные ограничения и лишь усилили атмосферу настороженного напряжения вокруг ученого. Каплей, переполнившей терпение Зиновьева, оказался запрет на его выезд в Финляндию для участия в научном симпозиуме, полученный накануне отъезда. Зиновьев заявил публичный протест через иностранную прессу, а через несколько дней отказался от партбилета.

3) Далее следовали „карательные меры”. В Институте философии была создана специальная комиссия по „делу Зиновьева”, его уволили с работы, лишили всех ученых степеней, званий, наград, изъяли из печати все его работы и даже в пылу чиновничьего усердия исключили из философского общества (в котором он не состоял). Поощряемая сверху „кампания” властей против известного ученого не только не вызывала тени протеста со стороны основной массы его коллег, но, наооборот, провоцировала их обличительную активность: многолетние коллеги и друзья требовали суда над „сволочью, которую проглядели” (Зиновьев 2008: 432). „Власти, писал Зиновьев, - отдали меня на съедение самим ученым, и те сделали свое дело" (Зиновьев 2008: 434).

4) Завершился процесс не просто изоляцией отщепенца и изгнанием его из коллектива, а „полным остракизмом” (Зиновьев 2008: 403): Зиновьева лишили гражданства и фактически выслали из страны, но „без скандала”, который мог бы привлечь интерес к его книгам, потихому, под видом приглашения Мюнхенского университета для двухгодичного чтения лекций. В августе 1978 г. ученый покинул родину, что расценил как „наказание за преступление”, которое ни он, ни его семья не совершили (Зиновьев 2008: 455). Так осуществился, по Зиновьеву, реальный процесс „выталкивания индивида в отщепенцы” при коммунизме.

В результате размышления над фактами своей жизни ученый пришел к убеждению, что и власти, и общество нуждаются в отщепенцах:

Отщепенцами люди становятся отчасти помимо воли - общество само выталкивает их на эту роль. Отчасти они становятся таковыми добровольно, в силу жизненного 
призвания. Общество борется с отщепенцами. Но оно вместе с тем нуждается в них (...) чтобы они сыграли роль, которую не хотят и не могут играть другие, „нормальные” люди. (...) это своего рода ритуальное жертвоприношение (Зиновьев 2008: 21).

Наличие отщепенцев, отступников, диссидентов, ренегатов необходимо для того, чтобы, борясь с ними, снимать возникающие время от времени в обществе негативные эмоции, направляя их в контролируемое русло. В тоталитарном государстве давление властей провоцирует накопление в обществе недовольства, которое ищет своего выхода: борьба с отщепенцем - и есть один из таких идеальных выходов. При этом публичная ,расправа” с отвергнутым не только нейтрализует негативную энергию в обществе, но и дает предостерегающий воспитательный урок для всех его членов. Возникает парадоксальная ситуация: отщепенцы берут на себя смелость выразить всеобщее недовольство, но именно за это их осуждают сами же недовольные, не способные к какому-либо протесту. Еще раз подчеркну, что особенность творческого метода Зиновьева состояла в органическом переплетении частного и всеобщего: личные жизненные проблемы рассматривались так же тщательно и глубоко, как и проблемы социально-исторического бытия; в своих общетеоретических выводах ученый опирался на собственный жизненный опыт и самоанализ.

Отщепенство для Зиновьева - это общественная позиция, которую выбирает личность, дистанцирующаяся от окружения, где доминирует борьба за социальные блага, господствует эгоизм и пренебрежение общечеловеческими нормами морали. Герой писателя - отщепенец-идеалист, является одиночкой, бунтующим практически против любого общественного строя, поскольку законы социального развития никогда не совпадают с развитием и потребностями конкретной человеческой личности, стремящейся к социальному идеалу.

Итак, два сюжета из истории отщепенства свидетельствуют не только о значимости самого специфического социального явления, существовавщего и существующего поныне в русской общественной жизни, но и о различных формах его жизненного и литературного выражения. Феномен отщепенства даже на материале двух текстов предстает достаточно многогранно. Назову лишь некоторые выявленные смыслы: отщепенство - противостояние; личный или общественный конфликт, 
бунт, протест; отражение определенных мировоззренческих позиций; полулегальность или нелегальность деятельности; утверждение, культ нового в противовес старому и отжившему; радикальность, революционность, нигилизм; свободное самоопределение личности; демонстративное заявление своей позиции перед обществом; самоутверждение; независимость; индивидуализм; одиночество; поведение и образ жизни; жизненное призвание; ритуальное жертвоприношение. Как видно, отщепенство является одним из ключевых понятий русской культуры, более подробную историю которого предстоит написать.

\section{Литература}

Даль В.И., 1979, Толковый словарь живого великорусского языка, т. 2, И-О, Москва.

Зиновьев А.А., 2008, Исповедь отщепенца, Москва.

Козьмин Б.М., 1982, Литература и история, вст. ст. и прим. Э. Виленской, Москва. Кропоткин П.А., 1966, Записки револючионера, Москва.

Кузнецов Ф.Ф., 1981, Публииисты 1860-х годов: Круг „Русского слова”. Григорий Благосветлов, Варфоломей Зайчев, Николай Соколов, Москва.

Кузнецов Ф.Ф., 1984, Шестидесятники, Москва, с. 53-54.

Михайлов А.В., 2000, Из истории ,нигилизма”, в: idem: Обратный перевод. Русская и западно-европейская культура: проблемь взаимосвязей, сост., подгот. текста и комм. Д.Р. Петрова, С.Ю. Хурумова, Москва, с. 537-623.

Морозов Н.А., 1933, Повести моей жизни, т. 1, Москва.

Соколов Н.В., 1984, Отщепенцы, в: Шестидесятники, сост. и автор вст. ст. Ф.Ф. Кузнецов, Москва, с. 166-304.

Струве П.Б., 1990, Интеллигениия и револючия, в: Вехи. Сборник статей о русской интеллигениии, репр. воспр. изд. 1909 года, Москва, с. 156-174.

Щербакова Е.И., 2008, „Отщепенцы”. Путь к терроризму (60-80-е годы XIX века), Москва. 
